\author{
Eleonora Jedlińska \\ ๑ https://orcid.org/0000-0002-4322-5563 \\ Institute of Art History, University of Łódź \\ eleonora.jedlinska@gmail.com
}

\title{
ANSELM KIEFER AT THE LOUVRE MUSEUM AND OLAFUR ELIASSON IN VERSAILLE: ON THE NARRATIVE SPACE OF A WORK OF ART
}

\begin{abstract}
Anselm Kiefer and Olafur Eliasson, even if divided by generational differences and the material of their art, they share a similar understanding of the function of the work as a narrative medium. The place where the work is exhibited, its historical value and the story it contains force us to reverse the conventionally accepted significance of the presence of contemporary art in two globally recognized, most important museums of France: Kiefer's at the Louvre and Eliasson's at Versailles.

The exhibition of the works of these artists at places that represent historical, symbolic and artistic significance both for the French, as well as the whole world, allowed their narrative function to extend and thus to change the perception of the place of a contemporary art exhibition. The connection of contemporary times with history is also an attempt to open the borders defined by the traditional location of the place. Both presentations aim to show how the perception of contemporary art can be changed when it is understood as a continuation of great historical narratives.

In 2007, Kiefer exhibited three works at the Louvre. The artist incorporated his works in the framework of the narrative - history, philosophy, religion, art history, tradition and modernity. In 2016, Eliasson presented sculpture-installations in the gardens and palace of Versailles, in the form of architecture and garden design works whose message is the anxiety and concern about the fate of the modern world. Just as illusory was the world in which the inhabitants of Louis XIV's Versailles lived, so is our own illusion of a world without borders, a world with endless natural resources, where our conscience is numbed by apparent actions to protect it from ecological disaster.
\end{abstract}

Keywords: Anselm Kiefer, Olafur Eliasson, Louvre, Versailles, narrative, memory, history, ecology 
The works of the two contemporary artists, Anselm Kiefer and Olafur Eliasson (whose works I discuss in response to the proposed topic Narratives about art - Narratives of art) differ in terms of generational and ideological aspects, as well as the media they use. The main reason for these two artists to be the subject of my review here is their shared understanding of the importance of interactions between a work of art, carrying a narrative message specified by the author, the place of its exhibition and the reception of such interconnected space by the visiting audience. The exhibition of works by contemporary artists in two of France's most important museums: the Louvre and the Versailles - objects of exceptional historical, architectural and symbolic significance, as well as social and cultural value - determines their interpretation, extends their narrative function, as well as invites a new context in which the place itself and the works are to be read. It is also an attempt to cross the boundaries set by traditional positions of the vectors: artist - work - exhibition - recipient. Each of the vectors constructs its own and influences every other story, thus adding an intrinsic new value to the historic space of European architecture and the works of old masters.

At various stages of the construction of the palace (Palais du Louvre) and the gallery, which was later transformed into a museum, the greatest living art masters were invited to decorate the plafonds, stairs and make interior decorations. Sometimes they were commissioned to finish the work started by their predecessors years before.

When on February 6,1661 a fire broke out which destroyed the so-called Petite Galerie (its construction lasted for 15 years, from 1595 to 1610) located on the ground floor of the Louvre, it was decided to give it a new function. Galerie de Rois was founded. It is now called Galerie Apollon. Louis Le Vau (1612?-1670) was tasked with rebuilding the wing located on the banks of the Seine and he introduced significant changes between 1661 and 1663. Charles Le Brun (1619-1690) developed the program of decorations ${ }^{1}$. Portraits of French rulers were displayed there - the works of Jacob Bunel (1558-1614). Galerie Apollon was the first royal gallery and, twenty years later, it would become a model for the Hall of Mirrors at the Palace in Versailles, where, in the $21^{\text {st }}$ century, Olafur Eliasson, an Icelandic-Danish artist, would be showing his works.

1 See: N. Pevsner, Historia architektury europejskiej, vol. II, trans. Jan Wydro, Warszawa 1980, pp. 112-117. 
From the beginning of the nineteenth century, decorative works were over many years created in turns by Eugène Delacroix (1798-1863) and Joseph-Benoît Guichard (1806-1880). In 1849, Delacroix decorated the ceiling of Galerie Apollon by painting a monumental scene depicting Apollo knocking down a snake which occupies the central part of the gallery ceiling.

In 1947, Georges Salles ${ }^{2}$ invited Picasso to present his works in the Great Gallery, in the vicinity of the paintings of old masters. Also at the request of Salles, in 1952-1953, Georges Braque decorated the ceiling in former Henry II's apartments with a painting entitled Les deux oiseaux (Two birds) ${ }^{3}$. When, at the end of the 1980s, the renovation of the main body of the Louvre (Grand Louvre) was completed, the famous glass pyramid created by the Chinese architect Ieoh Ming Pei (1917-2019) was added, "assimilating" modernist structure 4 into the oldest part of the architectural environment which constituted the heart of the Louvre.

Originating in the 17th century, though abandoned for dozens of years, the idea of looking at the Louvre collection from the point of view of contemporary artists has enjoyed revival since 2003, taking up the issue of creating a work specifically for this place and in reference to the objects displayed around again. The intention to entrust artists with the selection of their own works, their choices of exhibition, incorporation of the works into the narrative of the museum, became a tradition of the Louvre. A special curator has been appointed, who is responsible for contemporary art and current exhibitions, such as the Counterpoints exhibition. Contemporary artists have been invited since 2003. Every year, as part of the Photo Month taking place in Paris, photographic works are shown next to the works of ancient art. Various large format photographs are displayed in the museum halls. The most obvious expression of the return of recent art to the Louvre is the strategy of commissions offered to artists from various countries to present their works there. Orders placed by the Louvre authorities let the audience, uninitiated and traditionally focused on old masters, to (informally, in a way) learn about the art of the $21^{\text {st }}$ century, whereby the Louvre constantly confirms its universal nature of an open and modern museum. From 2010, the year when Anselm Kiefer's works were included in the

2 Geroges Salles (1889-1966), art historian, director of the Musées de France in the years 1945-1957. With Jean Cassou, he initiated a new concept for the functioning of the modern art museum, so that art would become available to as many people as possible.

3 https://www.bing.com/search?q=Joan+Mir\%C3\%B3+a+Louvre+et+Georges +salle$\mathrm{s} \& \mathrm{q}=\mathrm{n} \&$ form=QBRE\&sp=-1\&Joan=pq+mir\%C3\%+B3and+louvre $(4 / 17 / 2020)$.

4 http://pei-architects.com/ (17/04/2020). 
permanent collection, Cy Twombly's works have also been exhibited (Salle des Bronzes), alongside François Morellet's (l'Escalier Leuful) and a few others'.

Anselm Kiefer at the Musée du Louvre: narratives about art.

Anselm Kiefer was invited to the Louvre in 2007. Born in 1945 in Donauschingen, the German artist was asked to create works that would be intended especially for the Louvre's spaces. Kiefer has been living and creating in France since 1993. For almost 15 years, he lived in Barjac, where he turned 35 hectares of his own estate into an art studio called Ribaute. In 2008, Anselm Kiefer settled in Paris.

Kiefer's sculptures, installations and paintings are shown in the northern staircase (so-called l'Escalier nord de la colonnade) designed in the nineteenth century by the architects of the Napoleon's era, Pierre Percier (1764-1838) and Pierre Fontaine (1762-1853) with a massive colonnade designed by Charles Perrault (1613-1688). The painting of Athanor and the sculptures Hortus conclusus and Danae are placed in two niches of the staircase, opposite to each other. $^{5}$

The artist's assumption was that his works should be located between two geographical and historical zones: Ancient Egypt and Babylon of the Sumerian period. ${ }^{6}$

The works of Anselm Kiefer were placed in the northern stairways of the colonnade, where they form, together with the southern stairs, a unique example of communication between two architects of Napoleon's period. The unfinished decoration of the northern marble stairways with columns in the Corinthian order comes from the 19th century. Empty arcaded niches of the eastern wall proved to be a fitting place to display contemporary sculptures.

As the author himself says, his first work shown at the Louvre is the autobiographical monumental painting entitled Athanor [ill. 1]. This work has been permanently included in the collection of the Museum. It is placed at the northern wall of the staircase landing (the north, so-called Assyrian, wing).

Athanor offers a key to interpret Kiefer's work. The artist uses motives of human presence in space and of the durability of original beliefs that empower the entity to function in the micro and macro world.

5 M.-L. Bernadac, Athanor, in: https://www.louvre.fr/sites/default/files/medias/medias_fichiers/fichiers/pdf/louvre-dossier-presse-anselm-kiefer.pdf (19.4.2020).

6 Entretien Jean-Marc Terrasse, Anselm Kiefer, in: Anselm Kiefer au Louvre, J.-M. Terrasse, Frontieres, en nous, hors de nous, nous - Entretien Jean-Marc Terrasse: Anselm Kiefer au Louvre, ed. du Regard, Paris 2007, pp. 21-22. 


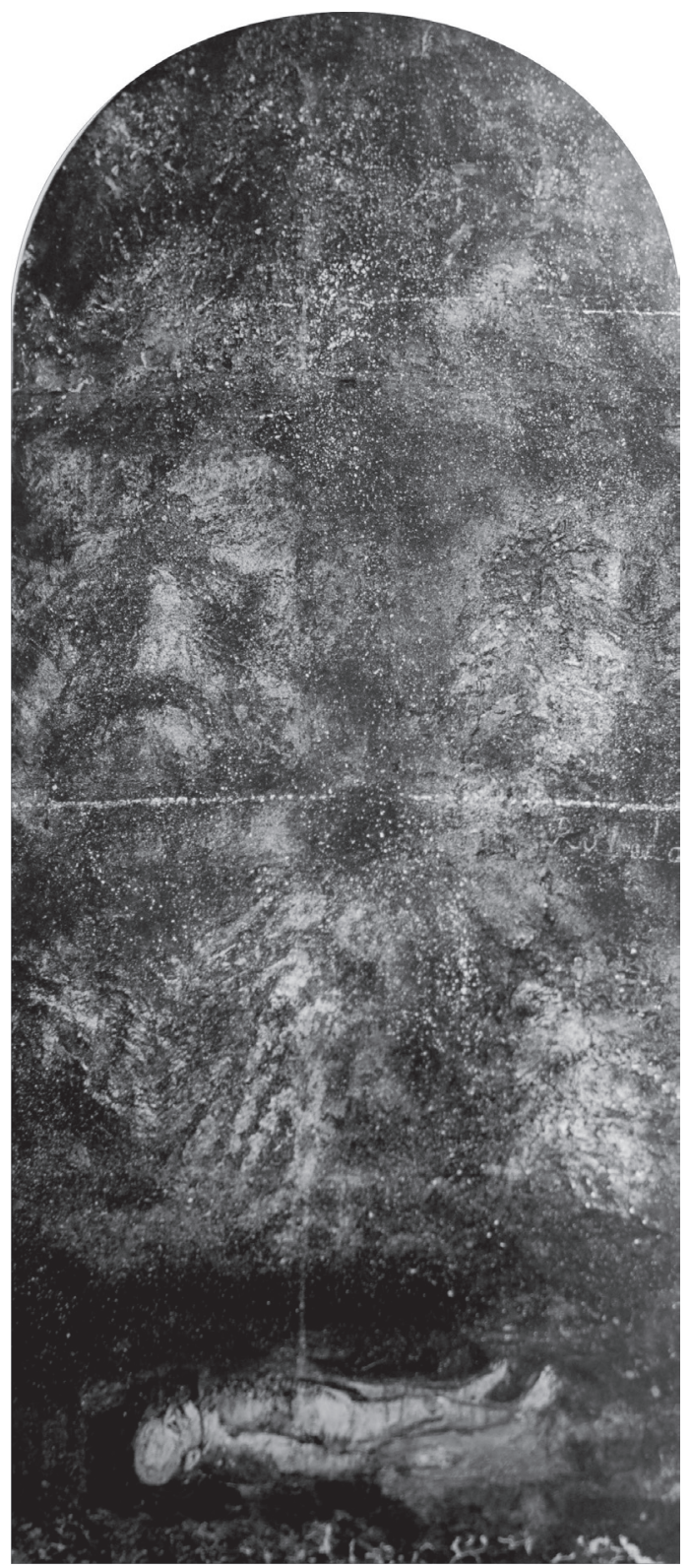

1. Anselm Kiefer, Athanor, 2007, emulsion paint, shellac, oil, chalk, lead, silver, gold, linen canvas. Permanent installation, Musée du Louvre, Paris.

Source of copy:

http://katatsumurinoyume.com/2019/08/anselm-kiefer-au-louvre-danae-et-hortus-conclusus html (22.06.20). 
Kiefer, following the path of medieval alchemists, designs internal experiences and transforms his thoughts into works using the painting matter. The artist often includes symbolic signs to express what cannot be expressed in words. Using symbolic language to communicate the phenomenon of personal experience, he penetrates the sources of his dreams, fears and the impression of being connected with the universe.

The repeatability of topics, quotes, references to mythology, literature, works of his own art and of other artists is one of the artist's defining features. Among the motives that reappear in his works in various configurations is the representation of a lying man. It seems to be a constantly present image of his inner life. A lone man lying on the ground - the artist's self-portrait - appears, for example, in the watercolor of 1971 Homme étendu avec une branche, Chuwawa Gilgamesh of 1980, in the picture Gilgamesh III from the series Gilgamesh and Enkidu in cedar forest (Gilgamesh und Enkidu im Zederwald III) of 1981, Sol Invictus of 1995, as well as in numerous sketches, studies and theme versions.

"Memory and forgetfulness are paradoxically related - that's how it is. I don't do anything other than looking for the relationships of my life with the past and the future. Here in this painting it is me, but not only me, this is my archetype. He is here. I am a today's man who remembers ancient times accurately. I'm here made of everyone," Kiefer says. "My memories, my past. The future is connected with the past but not mixed up. When I paint, I make movements that seem to contradict logic: I'm going into the past and at the same time into the future."

Athanor depicts a figure of a naked man lying on his back on eroded ground under the sky scattered with stars, his arms outstretched along the body. A lonely man, yet capable of maintaining a connection with the cosmos, the sky, the life of stars and meteors. ${ }^{8}$ Athanor is also a nocturnal landscape. The field is divided into three parts by clearly delineated horizontal lines painted with silver and gold. The upper one is the highest part of a dark night sky, while in the center you can read the outlines of constellations and, at the very bottom, a naked body is lying on cracked earth. There is a ray connecting the man's body with the sky, coming from his chest.

The sky part is dominant in the picture, but its essence is the man. In a conversation with Jean-Marc Terrasse, Kiefer emphasizes the unique significance of this work which, he says, is his spiritual self-portrait. ${ }^{9}$ The title denotes the

7 Jean-Marc Terrasse, Frontieres, en nous, hors de nous, nous - conversation with Anselm Kiefer, in: Anselm Kiefer au Louvre, Edit. du Regard, Paris 2007, p. 31, transl. from French E. Jedlińska.

8 See: M. Eliade, Traktat o historii religii, transl. J. Wierusz-Kowalski, Warszawa 1966, p. 48.

9 Jean-Marc Terrasse, op. cit., pp. 21-22. 
name of the alchemical furnace in which the philosopher's stone was burned using ordinary coal. Inside the furnace, there was the so-called philosopher's egg (Latin: ovum philosophicum, ampulla sphaerica) - an egg-shaped glass dish containing a gold and silver aggregate and tincture. In the philosopher's egg, the process of alchemical transformation of the philosopher's stone was to take place $^{10}$ - the process of transmutation of matter.

The Athanor canvas is over 11 meters high and 4.30 meters wide. It uses materials such as lead, shellac, oil, chalk and silver flakes. The outlines of the head and the face of the naked man picture the artist himself - the image known from numerous photographs. The man seen in the painting Athanor is dead or, as Marie-Laure Bernadac suggested in the catalog of the exhibition at the Louvre, in the state of meditation, shavasana position. In alchemical practices, chaos or, in other words, a dream-death state, can also be achieved through meditation. Kiefer depicted his own dead body, emaciated, lying on his back in a pit. Death, as the artist imagined it here, is a transgression of the human way of living. The soul of the deceased, depicted in the form of a luminous flow escaping from the body, is going straight to the starry sky. When describing myths, Mircea Eliade argued: "In religions that place that world in heaven or in some upper sphere, the soul of the deceased climbs up the paths, climbs on trees or trunks and goes to heaven." 11 The sky is imagined here as a starry ceiling and space which the man organically connects with by dying.

The night sky is thickly laid with putty, cracked layers of black paint, sometimes with a little bit of blue. White spots suggesting star nebulae or snow falling at night, scattered on the entire surface of the canvas, seem to bring out the light breaking through the darkness. Lead is the art material often used by Kiefer. The surface of this metal, when treated chemically, displays spectacular colors, shades of rust, cinnabar, blue, gray and silver, achieving "Cavernous" depth of the night sky, just like the one seen at night in the desert. Lead is saturated with symbolic meanings. When combined with Saturn, it was a symbol of melancholic, but also creative forces. In the alchemical tradition, which the artist directly refers to in this work, lead meant a spirit trapped in the matter. ${ }^{12}$

Halfway up and adjacent to the arch closing the picture frame, two horizontal lines are drawn in silver-gold. To the right-hand side of the painting, there are three inscriptions written by the artist: nigredo, albedo, rubedo, meaning three alchemical colors - black, white and red, corresponding to lead, silver and gold. To achieve transmutation, magnum opus (the philosopher's

10 Cf. CG Jung, Psychologia a alchemia, trans. R. Reszke, Warszawa 1999, p. 19.

11 M. Eliade, Kowale i alchemicy, trans. A. Leder, Warszawa 1993, pp. 104-105.

12 See R. Klibansky, E. Panofsky, F. Saxl, Saturn i Melancholia. Studia historii, filozofii, przyrody, medycyny, religii oraz sztuki. Transl. A. Kryczyńska, Kraków 2009, pp. 157-159. 
stone) undergoes four phases of change referred to by the names of the colors. Nigredo (black) symbolizes death. It corresponds to the stage at which all ingredients accept black color: "This is to bring the matter, matter prima, that is the liquid corresponding at the cosmological level to the original situation, to chaos ... Death represents regression to an amorphous state, it is a reconstruction of chaos." 13 By imagining his own body as given to the depth of Mother Earth with a ray of light (soul) connecting him with heaven, Kiefer follows the path of medieval Chinese alchemists. Microcosms, as interpreted by alchemical concepts, have their counterparts in human body organs - fire consuming the heart turns into mercury and the water around shines as lead. ${ }^{14}$ Therefore, man, as an equivalent of the microcosm, concentrates all the components in his body. The cosmos which creates vital forces ensures cyclical recreation. In alchemy, albedo means a purification process. The purpose of this phase is to regain the original purity and openness of the soul. Rubedo, like the philosopher's stone, is associated with red, meaning the state of spiritual integration with the universe.

Cracks visible on the canvas surface are filled with lead. It resembles streaks that water the desert in spring. Red-brown dirt (according to alchemical investigations, cinnabar provides constant renewal and hides the secret of rebirth through death), gray-pink in some places, is heavy and dry. A luminous flow emerges from the chest of the lying man, which, according to Kiefer, is a symbolic sign of the "spark rising towards the starry sky." 15 The man's body, dead or put into the deepest state of meditation, is imagined in Kiefer's work in the phase when it turns into aquatic fluid - bluish lead streaks illustrating this process are embedded in the cracks.

Throughout the work, a narrative is conducted referring to the belief that it is the thought process of the artist, intensity of his intellectual search and his feelings that are equal to the alchemical process of transmutation of basic elements, transition from one state to another. "A work of art is therefore the bearing where the metamorphosis takes place" - Bernadac. ${ }^{16}$ The historical space of the museum, combined with collections of works of art originating in the earliest eras and from different civilizations, became the "furnace" in which the "alchemical" transmutation, exchange of life for death or death for life happens.

13 M. Eliade, Kowale i alchemicy, op. cit. p. 116.

14 Compare W.-A. Martin, The Lore of Cathany or the Intellect of China, Wentworth Press, New South Wales, 2016, p. 60. (originally published in 1901).

15 Jean-Marc Terrasse, op. cit., p. 22.

16 M.-L. Bernadac Athanor, op. cit., p. 13. 
In the alchemical furnace, according to the laws of alchemy which Kiefer refers to, the principle of "equal exchange" applies, which is associated with the belief that an exchange process should sacrifice things of equal value. The use of the philosopher's stone was supposed to bypass this rule. The artist situates himself (Athanor is a self-portrait) at the place and the moment when the process of "equal exchange" is likely only when the modern man penetrates into the distant mythical past. A special exchange occurs between the author, history and the present day when he confronts his own achievements with art created millennia before. A romantic hero is a recumbent character often recalled in Kiefer's art. On the one hand and, according to the artist's explanations, he is an archetypal figure, a symbolic connection of the contemporary German with the great tradition of German history and culture. On the other hand, it is a dark tragic character entangled in Nazism by the memory of crimes committed by his ancestors, one that somehow takes responsibility and repents for the tragic events of the $20^{\text {th }}$ century. Kiefer believes that after a time of mourning that every artist (especially Germans born after 1945) should go through, the artist must return to creation, and that myths are the most universal source of our knowledge of ancient cultures, their durability and timeliness. In the world after Auschwitz - declares the artist, contrary to the commonly known Adorno theorem on the impossibility of art existence after the Holocaust - art should learn the power of thought and the works of the past - of Egypt, Syria, Mesopotamia, Greece, the Old and New Testaments, Kabbalah. The task of art is to indicate the universality of human beliefs and rituals common to many cultures, such as the rebirth of life after death. Therefore, Kiefer's work should be treated as the work of a painter of great historical narratives.

Athanor is also a metaphorical image of the artist Anselm Kiefer as "the last and first man", giving his half-dead body to "stones of light", golden shards of the celestial throne (stars) that reflect everything that happens on the earth. They show what happened to the soul after death and the place where it left. ${ }^{17}$ Athanor responds to the fragility of the present and the immortality of the past with the space-time measure.

Art is a means of connecting the worlds of the earth and sky, what is real and what is imagined. This dual aspect translates into a work of art. Kiefer often creates palimpsests when applying one layer over another; in this way, new images are created on old ones. Athanor is the work that consists of four canvases of the cycle Forêts sous la neige "... it was snowing all day..." - said Kiefer remembering the white covering the night. This unique concentration of

17 See: M. Eliade, Le chamanisme et les techniques archad'ques de l'extase, Bibliotheque historic Payot, Broché, Paris 2015, p. 135. 
meanings and signs confirms the artist's interest in the archaeological layers, a geological-like approach when what is covered by the passage of time is exposed - in art it is reunited - writes Marie-Laure Bernadac ${ }^{18}$.

At the exhibition Anselm Kiefer au Louvre, two sculptures were also presented: Danae and Hortus conclusus. Placed opposite each other in two niches of the staircase, they also relate to the issue of transmutation that concerns the artist.

The sculpture of Danae [ill. 2] refers to Greek mythology. It is ascetic and full of strong meanings at the same time. Its seemingly weak form is made of materials with symbolic meanings: lead, gold, steel and natural resins. A tall sunflower stem is growing from a pile of old books made out of lead, forming the base for the sculpture. The flower is withered, with no petals and the golden drops/seeds/tears of Danae are dropping down from its "heart". According to the myth ${ }^{19}$, Danae was the daughter of the king of Argos - Acrisius and Eurydice. ${ }^{20}$ The fate of Danae and her son, begotten by Zeus who visited the royal daughter in the form of golden rain, is a prologue to the tale of Perseus. The appearance of Perseus crosses the border between the myth and fairy tale. Zygmunt Kubiak writes: "We are entering the field of fairy tales. Don't underestimate it. The fairy tale may contain ancient elements, even older than in myths." ${ }^{21}$ In his conversation with Terrasses, Kiefer often invoked the importance of borders as inevitably accompanying us in both mental and bodily feelings, rooted in myths, fairy tales, and books of the Old and New Testament. Danae is "embodied" in the dead sunflower, as Kiefer introduced it, symbolizing the sun that she became deprived of by her father's decision. The sunflower is considered a prosperous flower - presented here as dying, it will regain life by alchemical transmutation. In Kiefer's sculpture, the golden drops, i.e. "golden rain" which Zeus impregnated Danae with, are a sign of strength. The sculptor, however, goes to the place where the "hidden sphere", i.e. the sphere of relation-

18 M.-L. Bernadac, op. cit., p. 15.

19 E. M. Berens, The Myths \& Legends of Ancient Greece and Rome, MetaLibri, Amsterdam 2009, pp. 26-27 http://metalibri.wikidot.com (26.4.2020).

20 Z. Kubiak, Mitologia Greków i Rzymian, Warszawa 1997, pp. 434-444: „... a daughter was born, beautiful Danae. The king asked the oracle and received the answer that his male descendant, grandson, the son of Danae, will kill him. So he built an underground chamber (...) and imprisoned his daughter in it. But Zeus chose Danae and managed to haunt her in the form of golden rain falling from the prison ceiling into her bosom. That's how she conceived Perseus. ... Acrisius heard his voice from Danae's prison. He did not want to believe in the fatherhood of Zeus. ... he ordered a wooden crate to be made. Danae and the child were placed in it and the chest was thrown into the sea.... fisherman Dictys pulled the crate from the sea and took in the mother and her child who grew up in Dictys's home. This is how the story of Perseus begins.” trans. Eleonora Jedlinska.

21 Ibid, p. 435. 


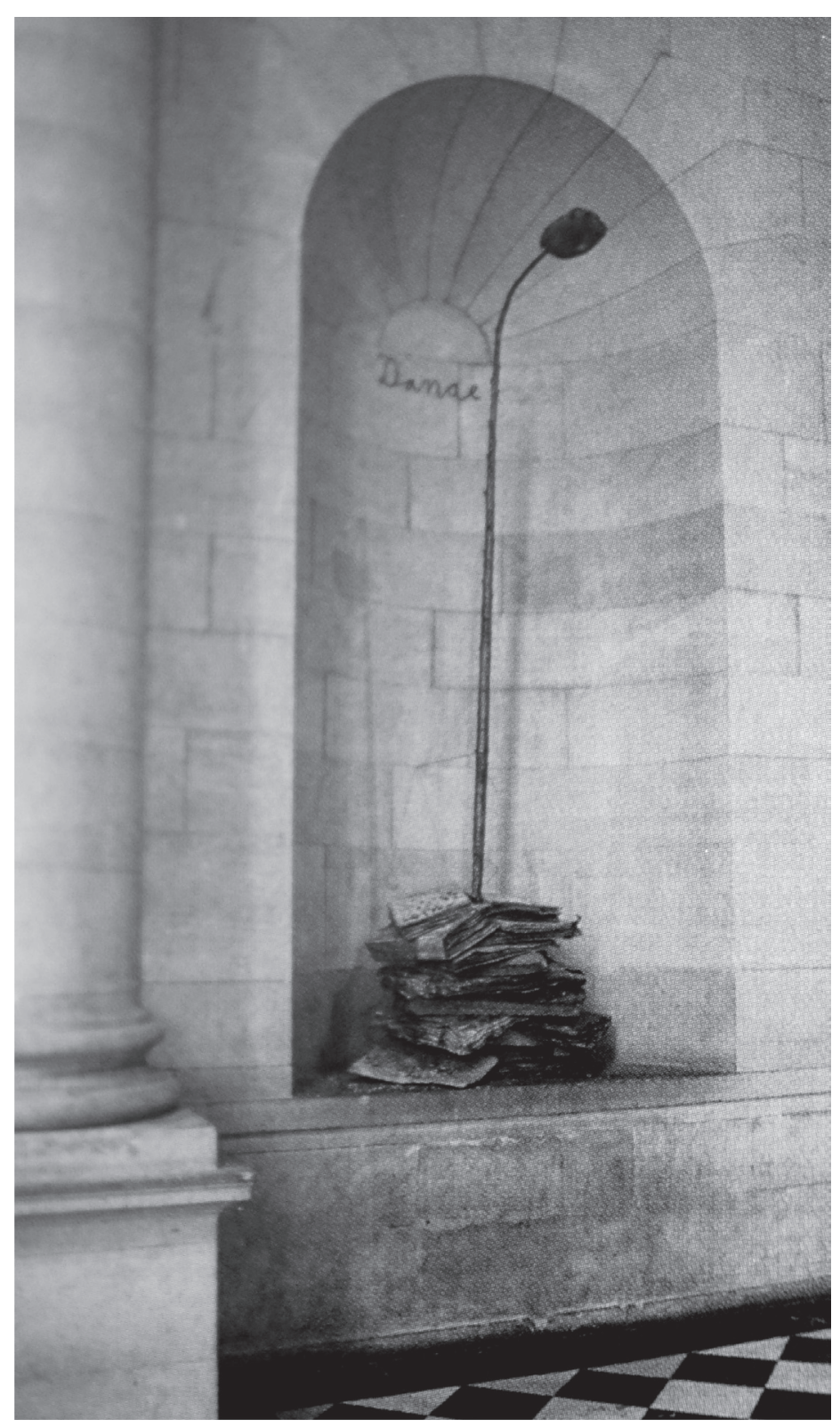

2. Anselm Kiefer, Danae, 2007, lead, gold, metal, resin. Musée du Louvre, Paris. Source of copy:

http://katatsumurinoyume.com/2019/08/anselm-kiefer-au-louvre-danae-et-hortus-conclusus html (22.06.20). 
ships, is located alongside the worlds of truth, good luck and pride. Danae will give birth to a child (Perseus) who will be entrusted to water. Eliade writes that he "would be exposed to death and, at the same time, had a chance that his life would go differently than the lives of other people. Under the protection of cosmic elements, an abandoned child often becomes a hero, a saint or a king."22 The moment when a child who is exposed to death appears, coincides with an initiating moment, such as the creation of the cosmos, the rise of a new world.

Kiefer's ancient Greek Danae is positioned in a kind of dialogue with the New Testament's Mary. In the niche opposite to Danae, there is the sculpture Hortus conclusus made of plaster, wood and shellac. Garden of the Virgin Mary - hortus conclusus soror mea hortus conclusus fons signatus / You are a closed garden, sister, bride, closed garden, source sealed [Biblia Tysiaclecia, PnP 4:12].

The sculpture Hortus conclusus [il. 3] is a small mound formed from shellac and plaster, suggesting dried, eroded soil which metaphorizes, according to the artist's statement, the hill on which Christ was crucified (Calvary, the Skull Hill). In the mound placed in the niche opposite the sculpture of Danae, twelve flowers are stuck: roses, sunflowers, carnations. Dead or touched by a disease, their dried petals are falling off their inclined heads, while some have broken stems. Kiefer's work with the title referring to one of the most important motifs of Christian iconography, i.e. the representation of Virgin Mary with the Child in the Garden, a symbol of the virginity of the Mother of God, is a response to the permanence of the theme in contemporary art. This work is also an indication of the connections between the Greek myth and Christian texts. It discovers the boundaries separating the fate of Danae's and Virgin Mary's son. The land that could not give life to the flowers is a symbol of Christ's death on the Skull Hill, of the tragedy that befell people in the 20th century and the futility of fixing it. Hortus conclusus, as the earthly reflection of Paradise in the interpretation of the German artist, is an image of melancholy after the catastrophe of World War II. By referring to the medieval motif of hortus conclusus as an image of Eden created by God for man, the perfect "home" inhabited by Adam and Eve living in harmony with nature, and presenting this "home" as if after a fire, the artist transferred the biblical myth into the present time. The myth of paradise lost speaks of the human loss of harmony with the world. Thus, hortus conclusus is the embodiment of longing and the dream of return. Athanor seems to be an expression of reconciliation between the world of the sacred and the world of profane that may occur through death. Anselm Kiefer confronts his melancholic sculpture with the myth of Danae and presents the image of his defenseless body open towards the cosmos. Athanor follows the path of those

22 M. Eliade, Traktat o historii religii, op. cit., p. 248. 


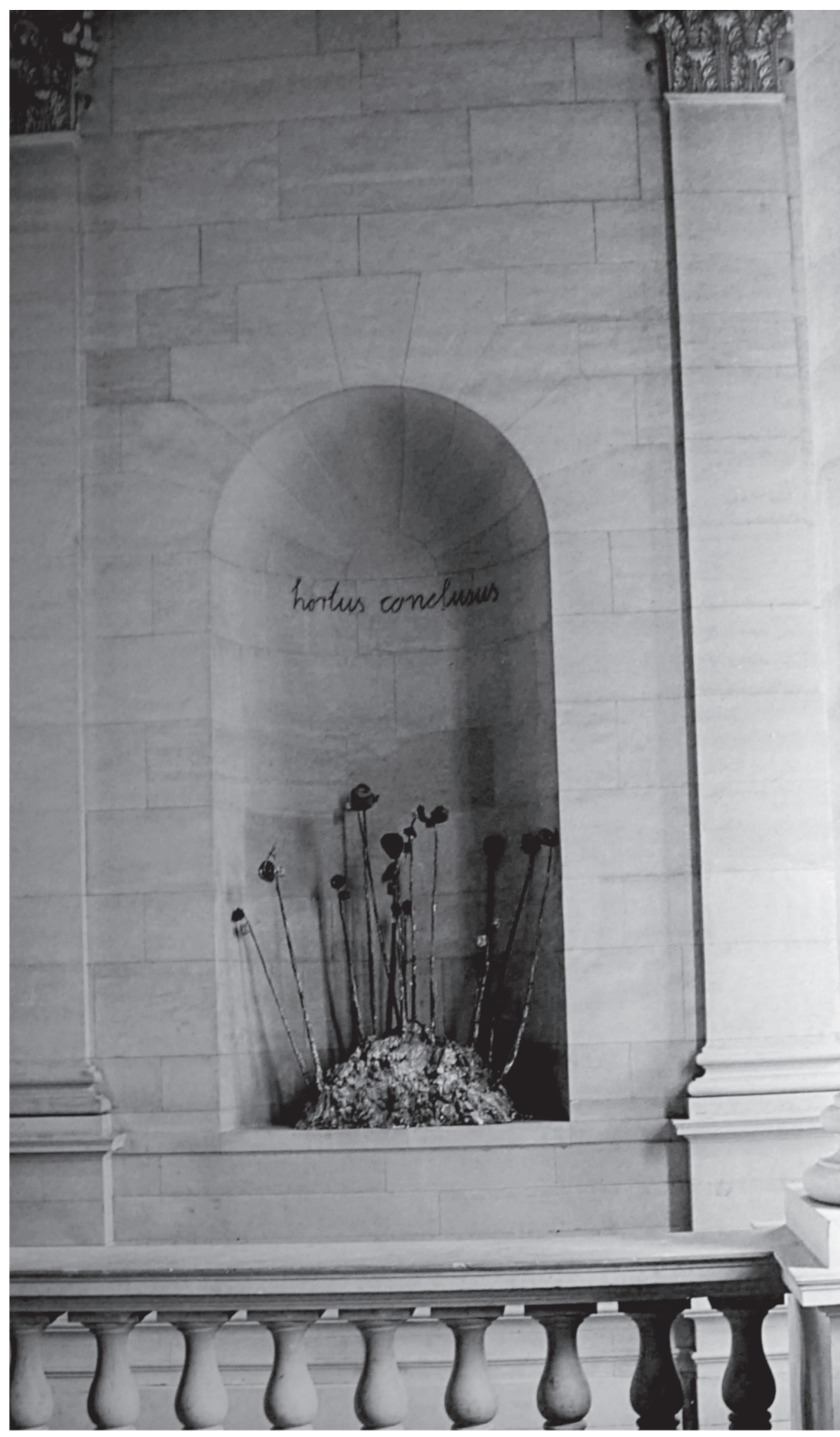

3. Anselm Kiefer, Hortus conclusus, 2007, plaster, shellac, emulsion, wood, resin, Musée du Louvre, Paris 2007.

Source of copy:

http://katatsumurinoyume.com/2019/08/anselm-kiefer-au-louvre-danae-et-hortus-conclusus. html (4.12.2020) 
who try to connect various and distant civilizations, and different religions. It indicates how important our knowledge and understanding of the history and culture of others is, including the most distant civilizations. These three works by the contemporary German artist who is striving to face the grimmest events in the history of his nation, are shown at the Louvre in the vicinity of the art of Sumer, Mesopotamia, Egypt and Greece, defining a line of continuity in

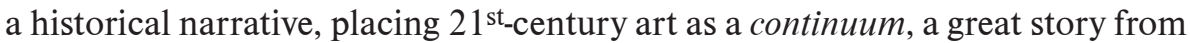
the "beginning of the myth".

With full awareness, Kiefer incorporates his work into the framework of great narratives - history, philosophy, religion, mental boundaries and the universality of the art of all eras. Thanks to being offered the walls of the Louvre Museum and given the surroundings of the ancient art of the East as a habitat for his works, the artist tells the story of the relevance of ancient civilizations in the life of the modern man and of the heritage of the past, as he draws our attention to our connections (metaphysical, alchemical, religious, philosophical, etc.) with the most distant cultures. According to the curator responsible for the presence of contemporary $\operatorname{art}^{23}$ at the Louvre Museum, it has become a place where emphasis is put on the importance of how the connection of the present time with the past can be conducive to building and rebuilding historical narrations, while allowing visitors to visualize the inseparability of ancient art from memory and history.

\section{Olafur Eliasson at Versailles: art in narrative space.}

The presentation of Olafur Eliasson's spectacular artistic installations in the palace and the gardens of the Versailles took place in 2016. It emphasized the phenomenon of the influences of European contemporary art on French history, culture and art, as well as of the relationships they have with each other. Just like the sculptures of Anselm Kiefer exhibited at the Louvre, these artworks also caused a change in the perception of modern art understood as a continuation of great historical narratives. While addressing the current problems of the modern world by being incorporated into the architecture of Versailles, Eliasson's works also "revived" baroque chambers, rooms, staircases and gardens of the palace's complex, inviting a new look on its past and present.

23 Marie-Laure Bernadac (born in 1950), French art historian and curator. She worked at the Picasso Museum in Paris (1989-1992), then headed the Cabinet of Engravings at Center Pompidou in Paris; she is currently the general curator responsible for contemporary art at the Louvre Museum. 
The refined, sensual art of Olafur Eliasson is oscillating between sculpture, installation, architecture and sciences with beauty and respect. It dwells on what is original and what is necessary for the human: light, space, water, color and our perception of those.

The works of Eliasson, who has Danish-Icelandic roots, have been shaped by the place of birth, education at the Royal Academy of Fine Arts in Copenhagen and a scholarship in New York. He was born in 1967 in Copenhagen. In 1993 he moved to Cologne, then to Berlin. In his art, Eliasson explores the boundaries between rationalism founded on mathematics, physics, ecology, architecture and sociology, and the power of magic and mysticism.

The recurring motives in Eliasson's works are the four elements: water, earth, air and fire. He is fascinated with their impact on the five basic senses: touch, smell, sight, taste and hearing. As part of these interests, works such as Pedestrian Vibes Studies, Time Vibes Studies - movement and vibration (2004), 3-5 Dimensional Endless Sound Study, LED Model Studies - sound recording (2005) - interaction of radio waves, sound waves and natural waves (e.g. sea waves) were created. In his early works, Eliasson drew particular attention to the issues of color perception, as well as relationships between light and color. His projects frequently assume the involvement of viewers - "Real art exists in collision with the viewer," 24 says the artist. Including the spectator in the frame of the work is to show how important participation in experiencing the surrounding reality is and how important it is to realize that a perception is not an objective experience.

Exhibitions have been organized in the interiors of the royal palace in Versailles. Contemporary artists, whose works have been presented there since 2008, have included: Jeff Koons, Takashi Murakami and Anish Kapoor. The creators have referred to the architecture and decor of the Palace by provoking or engaging in an ambiguous "dialogue" with its history (e.g. Anish Kapoor).

From June 7 to October 30, 2016, the gardens and interiors of the Palace of Versailles became the venue for the most interesting artistic events by Olafur Eliasson. ${ }^{25}$ Eliasson's installation entitled Versailles was aesthetically and ideologically intertwined with the sophisticated architecture of the palace's complex and its gardens. Respectful of the achievements of the royal architects of the French Baroque ${ }^{26}$, the artist created a unique political and historical bridge,

24 A. Pacquement, C. Pegard Catherine (2016), Olafur Eliasson. Versailles 7 juin - 30 octobre 2016 edit. Château et les Jardins par la Cour du Château de Versailles, Versailles 2016, pp.

25 A. Serafin, The Louvre Now Accepts the Living, „The New York Times” October, 21, 2007. https://www.nytimes.com/2007/10/21/arts/design/21sera.html (2.5.2020).

26 Architects: Louis Le Vau (1612-1670) and Jules Hardouin-Mansart (1640-1708); interior design by Charles Le Brun (1619-1690); gardens - André le Nôtre (1613-1700). 
"leading" viewers towards the past, while simultaneously provoking reflection on the condition of the present day. He realized his vision by using elements which constitute the splendor of the seat of the kings of France and provoked viewers to see the familiar place differently. Believing that art contributes to reality and the sense of time, as well as shapes the society and global community, Eliasson accomplished a work that introduces a new way of perceiving the Versailles. His installation consisted of nine works. Six were presented in the palace's rooms, three in the gardens. They were giant, slowly rotating mirrors, water and solar installations (The Curious Museum, Solar Compression, Deep Mirror, The Gaze of Versaille) [ill. 4].

In the gardens, installations referring to the element of "retained" water were created (Fog assembly, Waterfall [ill. 5] - the waterfall at Le Grand Canale - the main water pools located on the central axis of the gardens). The fountain at La Colonnade (Glacial Rock Flour Garden) [ill. 6] was filled with fifty tons of sand brought from Greenland, formed from rocks wiped out by a glacier. The artist's intention was to draw viewers' attention to global warming threatening the Earth, as well as to a sense of security and the illusionary sustainability of the beautiful royal park. The heroine of this installation was the baroque statue of Persephone, here helplessly leaning over the dry earth that fills the garden pool at the Versailles.

Eliasson points to the power of light and the illusion and uncertainty of light reflection. The world seen through lenses and reflected by mirrors is a metaphor of the illusion of power and omnipotence in which an absolute monarch lived, trying to subordinate his subjects and the surrounding nature. ${ }^{27}$ "The windows of the palace, overlooking the main royal courtyard, were a permanent view post in the past" - Eliasson explains the concept for the installation entitled The Gaze of Versaille. In the windows of the building, the artist placed spherical mirrors, blends and lenses resembling huge eyeballs, thanks to which viewers could see both the interior and what was happening in the courtyard. ${ }^{28}$ The reality seen from the heights of the royal windows, the possibility to observe the events in the courtyard and what was happening inside, meant that all the visitors found themselves in a continuous network of glances. "I ask myself: how do you, the visitor, view this iconic site? What does it do to you? Have we all become kings?" - Eliasson commented on his implementation. ${ }^{29}$

27 https://www.yatzer.com/olafur-eliasson-versailles/slideshow/20 (3.1.2020).

28 During the reign of Louis XIV Bourbon, called the Great King the Sun, who ruled France for 72 years, Versailles was inhabited by 10,000 people who were controlled by the king using a specially designed hierarchy and etiquette.

29 https://olafureliasson.net/archive/exhibition/EXH102421/olafur-eliasson-versailles (4.1.2020). 


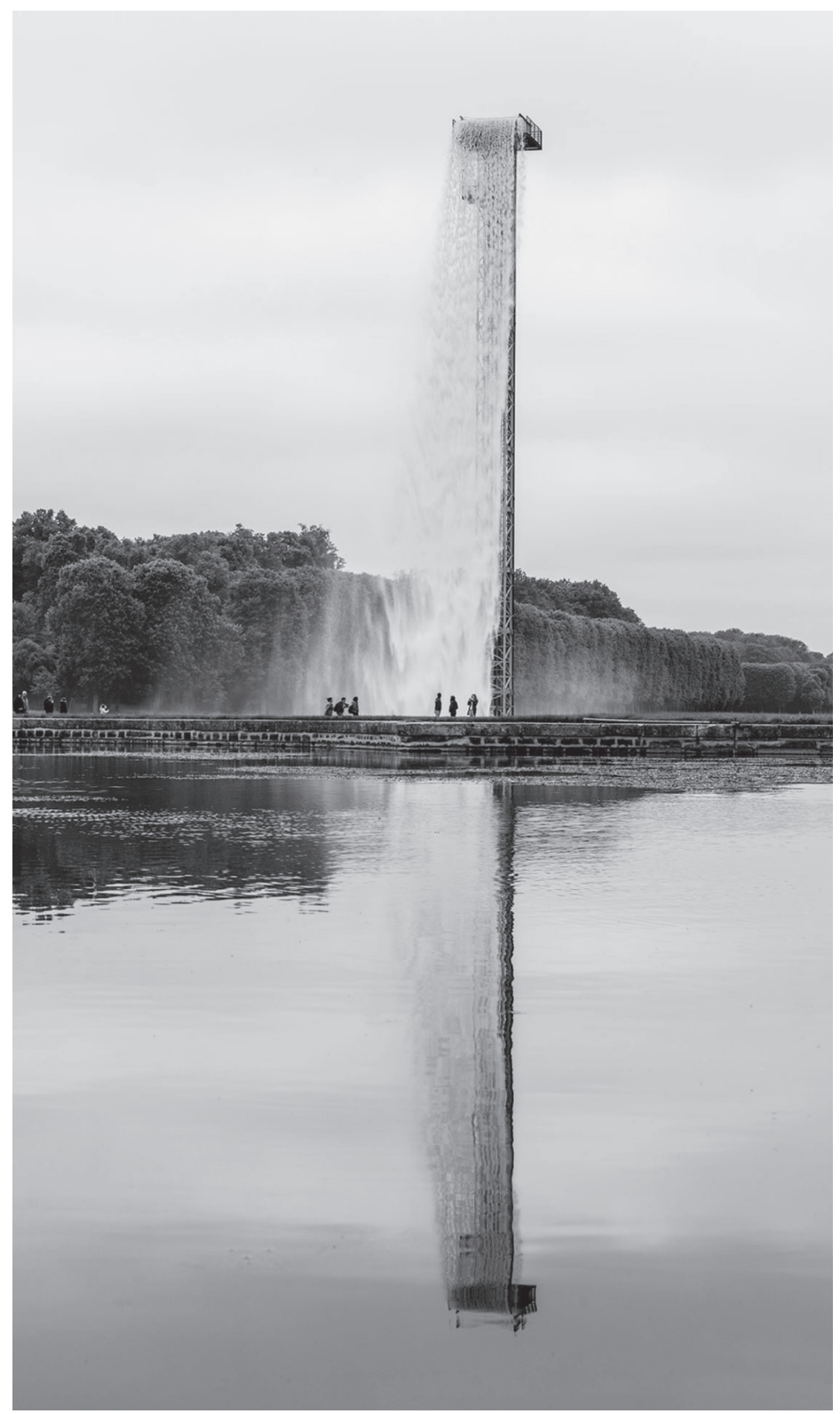

4. Olafur Eliasson, Waterfall at the Palace of Versaill. crane, water, stainless steel, pump system, hose and ballast. [Courtesy Anders Sune Berg; Neugerriemschnieder, Berlin: Tanya Bonak dar Gallery, New York and Olafur Eliasson].

Source of copy:

https://www.archpaper.com/2016/06/olafur-eliasson-versailles/ (27.6.2020). 


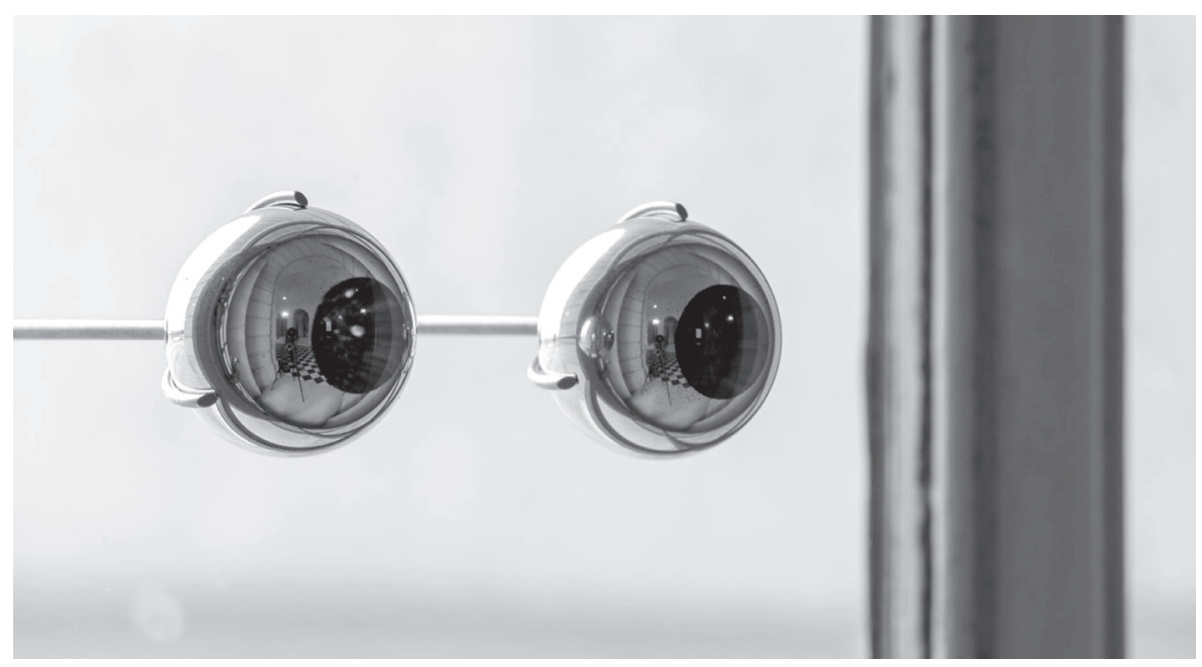

5. Olafur Eliasson, The gaze of Versailles, glass sphere, gold, brass, in two parts. (Courtesy Anders Sune Berg; Neugerriemschnieder, Berlin; Tanya Bonakdar Gallery, New York and Olafur Eliasson].

Source of copy:

https://www.archpaper.com/2016/06/olafur-eliasson-versailles/ (27.6.2020).

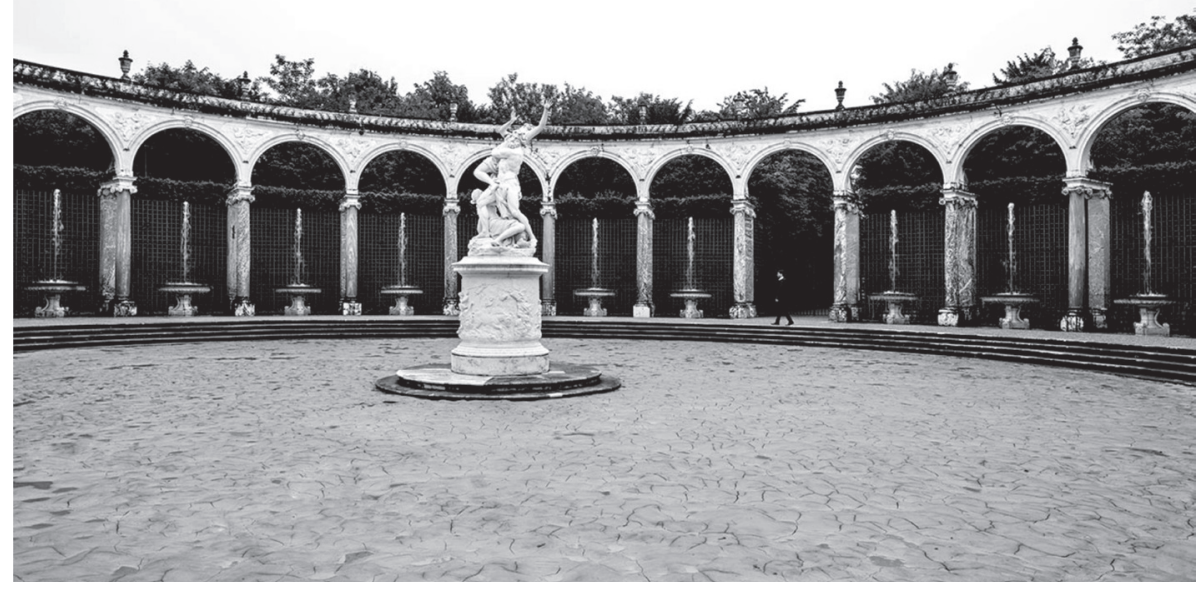

6. Olafur Eliasson, Glacial Rock Flour Garden - Proserpine, 2016, installation view, Place de Versaille, 2016, (Courtesy Anders Sune Berg; Neugerriemschnieder, Berlin; Tanya Bonakdar Gallery, New York and Olafur Eliasson].

Source of copy:

https://www.Olafur Eliasson's freestanding waterfall in Versailles (publicdelivery.org) (4.12.2020). 
While oscillating between architecture, science and history, and touching social issues, Olafur Eliasson draws our attention to individuality in the perception of reality. Observing and interpreting the subsequent installations by this artist becomes a journey into the complex areas of his creative and ideological inquiries. Encounters with such art evoke our desire to look at the world around us through the prism of science and a kaleidoscope of illusions. Eliasson works express delightful modesty of forms without resorting to the 'effects' of arte povera. The art created by Olafur Eliasson provokes viewers to immediately absorb, assimilate and sense it, and to immerse in its brightness, smell, illusion and transience.

We remain under the influence of Eliasson's installations, enchanted by their aesthetics and attentiveness. We contemplate his reflections on the beauty and fragility of our world whose existence solely depends on us.

Anselm Kiefer and Olafur Eliasson are different in terms of their experiences, life stories, the matters of art they create and the contexts they explore. What connects these creators is the belief that a perception of a work of art, carrying an eloquently outlined narrative, depends on the historical value of the place of its exhibition, which consequently enhances the meaningfulness of the story contained in the work itself. The presentation of works of worldfamous contemporary artists at two of the most important French museums, the Louvre Museum and the Palace of Versailles - places of exceptional historical, architectural and symbolic significance, provokes analyses, extends their narrative role and forces us to perceive both the place and the works of art in a new modern way.

\section{BIBLIOGRAPHY:}

Berens Edward M. (2009) The Myths \& Legends of Ancient Greece and Rome, MetaLibri, Amsterdam 2009, pp. 26-27, http: //metalibri.wikidot.com (26.4.2020).

Bernadac Marie-Laure, Athanor, https://www.louvre.fr/sites/default/files/medias/medias_fichiers/fichiers/pdf/louvre-dossierpresse-anselm-kiefer.pdf (19.4.2020).

Człowiek, który ujarzmia żywioły, Jana Pelczar's interview with Olafur Eliasson "Przekrój” 2019, no. 2 (3565), pp. 152-153. 
Eliade Mircea (1966) Traktat o historii religii, transl. Wierusz-Kowalski Jan, Warszawa, Książka i Wiedza.

Eliade Mircea (1993) Kowale i alchemicy, transl. Leder Andrzej, Warszawa, Fundacja Aletheia.

Eliade Mircea (2015) Le chamanisme et les techniques archad'ques de l'extase, Paris, Bibliotheque historic Payot, Broché.

https://www.bing.com/search?q=Joan+Mir\%C3\%B3+a+Louvre+et + Georges + salles\&qs=n\&for$\mathrm{m}=\mathrm{QBRE} \& \mathrm{sp}=-1 \& \mathrm{pq}=$ joan + mir\%C3\%B3+a+louvre (17.4.2020).

http://pei-architects.com/ (17.4.2020).

http://exspace.pl/articles/show/1717, 21. 10. 2018. (4.1.2020).

https://mfiles.pl/pl/index.php/Protok\%C3\%B3\%C5\%82_z_Kioto (2.1.2020).

https://archirama.muratorplus.pl/architektura/szklana-harpa-concert-and-conference-center-wreykjaviku-wspolprojektowal-ja-olafur-eliasson,67_1260.html (30.12.2019).

https://olafureliasson.net/archive/artwork/WEK100727/your-black-horizon (2.1.2020).

https://www.yatzer.com/olafur-eliasson-versailles/slideshow/20 (3.1.2020).

https://olafureliasson.net/archive/exhibition/EXH102421/olafur-eliasson-versailles (4.1.2020).

https://www.yatzer.com/olafur-eliasson-baroque-baroque (5.1.2020).

http://www.tanyabonakdargallery.com/artists/olafur-eliasson/series (5.1.2020).

Jung Carl Gustav (1999), Psychologia a alchemia, transl. Reszke Robert, Warszawa, Wydawnictwo Wrota.

Klibansky Raymond, Panofsky Ervin, Saxl Fritz (2009) Saturn i Melancholia. Studia historii, filozofii, przyrody, medycyny religii oraz sztuki, transl. Kryczyńska Anna, Kraków, Universitas.

Kubiak Zygmunt (1997) Mitologia Greków i Rzymian, Warszawa, Świat Książki.

Martin William Alexander (2016) The Lore of Cathany, or, the Intellect of China, Wentworth Press, New South Wales.

Pacquement Alfred, Pégard Catherine (2016), Olafur Eliasson. Versailles 7 juin - 30 octobre 2016, edit. Château et les Jardins parla Cour du Château de Versailles.

Pevsner Nikolaus (1980) Historia architektury europejskiej, vol. II, transl. Wydro Jan, Warszawa, Arkady.

Pietkun ks. Witold (1954) Maryja Matka Chrystusa. Rozwój dogmatu maryjnego, Warszawa, PAX.

Terrasse Jean-Marc (2007) Frontieres, en nous, hors de nous, nous - Entretien Jean-Marc Terrasse, Anselm Kiefer, in : Anselm Kiefer au Louvre, edit. du Regard, Paris, pp. 21-34. 


\section{O NARRACJI DZIEŁA SZTUKI W PRZESTRZENI NARRA- CYJNEJ: ANSELM KIEFER W MUZEUM LUWRU I OLAFUR ELIASSON W WERSALU (streszczenie)}

Artykuł poświęcony jest dziełom dwóch wybitnych artystów współczesnych: Anselmowi Kieferowi i Olafurowi Eliassonowi. Dzielą ich różnice pokoleniowe, światopoglądowe, tworzywo ich sztuki, łączy podobne pojmowanie funkcji dzieła, jako nośnika przekazu narracyjny. Miejsce w jakim dzieło jest wystawiane, historyczna wartość, mieszcząca się w nim opowieść zmuszają do odwrócenia, przyjętego przez konwencje, znaczenia obecności sztuki współczesnej w dwóch najważniejszych muzeach Francji o światowym znaczeniu: Kiefera w Luwrze i Eliassona w Wersalu. Ekspozycja dzieł tych artystów w miejscach, będących dla Francuzów, także dla świata, obiektami o znaczeniu historycznym, symbolicznym i artystycznym, pozwoliło rozszerzyć ich funkcję narratywną, odmienić tradycyjne postrzeganie miejsca wystawienia sztuki współczesnej. Złączenie współczesności z historią to także próba otwarcia granic wyznaczonych przez tradycyjne sytuowanie miejsca - dzieła sztuki - artysty - odbiorcy. Celem obu prezentacji było wskazanie jak można zmienić postrzeganie sztuki najnowszej, gdy pojmowana jest jako kontynuacja wielkich narracji historycznych.

W 2007 Kiefer w Luwrze wystawił prace, które zostały wykonane na prośbę kuratorów: Athanor, Danae i Hortus conclusus (2007). Artysta włączył swe dzieła w ramy narracji - miejsca, historii, filozofii, religii, historii sztuki, tradycji i współczesności. W 2016 Eliasson w ogrodach i pałacu w Wersalu zaprezentował instalacje-rzeźby, włączając w historyczną architekturę i założenia ogrodowe dzieła, których przekazem jest niepokój i troska o losy współczesnego świata. Tak jak iluzyjny był świat, w którym żyli mieszkańcy Wersalu Ludwika XIV, tak i my obecnie trwamy w iluzji świata bez granic, świata o niekończących się zasobach natury, uspakajając swe sumienia pozornymi działaniami mającymi chronić nas przed katastrofą ekologiczną, której sami będziemy winni - mówi Eliasson.

Słowa klucze: Anselm Kiefer, Olafur Eliasson, Luwr, Wersal, narracja, pamięć, historia, ekologia

Eleonora Jedlińska - PhD, after habilitation, professor at the Institute of Art History, University of Łódź. Lecturer in modern and contemporary art history, theory and criticism of art. A member of the AICA, president of the Łódź branch of the Polish Institute for World Art Studies, a member of the European Association of Jewish Studies and World Jewish Studies. Author of the books: Sztuka po Holocauście / Art after the Holocaust (2001), Polska sztuka wspótczesna w amerykańskiej krytyce artystycznej w latach 1984-2002 / Polish contemporary art in American art criticism 1984-2002 (2005), Powszechna wystawa światowa w Paryżu w 1900 roku. Splendory Trzeciej Republiki / Universal World Exhibition in Paris in 1900. Splendors of the Third Republic (2015), Ksztatty pamięci. Wybrane zagadnienia sztuki wspótczesnej / The shapes of memory. Selected issues of contemporary art (2019). 